\title{
Punishment of Criminals of Trafficking in Persons: Legal Perspective on International Guidelines and Indonesian Practices
}

\author{
Farhana Farhana*
}

Universitas Islam Jakarta, Indonesia

\begin{abstract}
The background of this study is that penalization is not only oriented towards the perpetrators of crimes of trafficking in persons but also oriented to the interests of victims and the community so that criminal justice aims to integrally protect various interests. The study aims to identify the punishment of criminals of trafficking in persons based on the interests of victims in Indonesian court practices as outlined by some regulations and the international community as outlined by the United Nations Office on Drugs and Crime (UNODC) and United Nations Convention Against Transnational Organized Crime (UNTOC). Considering that the study is a transnational crime, the point of view used in this study is clear to analyse the perspective of the national community and the international community. Hence, the standard imeasuring instrument used the perspective of international justice and its practical implementation by the Indonesian court. By using the library research method, the results showed that trafficking crimes are considered serious crimes by the international community. In regulating human trafficking, every country has laws regarding trafficking crimes by the applicable legal system. The theoretical contribution of this study is that each human trafficking crime case has different characteristics due to the condition of the perpetrator, the victim, the situation when the trafficking crime was committed. Therefore, as a practical contribution, the Indonesian court considers these factors which can be considered as a weighting or a reduction in sentence. The problem is incriminating and mitigating factors that must be considered in imposing penalties against traffickers. The study offers originality in investigating the factors which are burdensome and mitigate in imposing crimes against traffickers. The findings underline the principle of criminalization as the basis for imposing penalties on perpetrators of trafficking in persons by taking into account the factors of weighting and mitigation of punishment, in which the proportional principle takes precedence in addition to the other principles.
\end{abstract}

Keywords: Criminology, perpetrators, crimes, trafficking in persons, the international standard, court practice, Indonesia.

\section{INTRODUCTION}

Trafficking in persons is increasingly widespread and complicated, and trafficking in persons is extraordinary crime, so the handling done is extraordinary. Extraordinary crimes are transnational and organized crimes. International crime has an extraordinary impact on humanity. Transnational crime describes crimes that occur in international and transnational crimes that include two States, which have the nature of crossing the border as a part of a crime. Transnational crime requires that there is a link between the jurisdictions of two or more countries, between States that are victims or are severely harmed because of the crime in question, crimes of trafficking in persons between the sending State and the receiving country (Atmasasmita, 2016; Nuraeny, 2015). Trafficking in persons can occur in two regions but in the national territory in the sense of occurring in a State. As for organized crime or syndicate crime: a criminal act committed by a group (group) of crime that is systemized by social structures by seeking the ultimate goal of profits derived from illegal actions, this crime uses various marketing methods/techniques with

*Address correspondence to this author at the Universitas Islam Jakarta, J. Balai Rakyat No.37, Utan Kayu Utara, Jakarta 13120, Indonesia;

E-mail: farhana.uid@yahoo.com threats, extortion, smuggling and its products such as narcotics, sex, gambling, moneylenders, pornography that are beyond the reach of the law (Ali \&Pramono, 2011).

Global data on human trafficking shows that 40.3 million people worldwide are victims of trafficking, $81 \%$ of victims of forced labor and $75 \%$ of women more than 10 million victims are children and around 15.4 million are forced to marry. More than $54 \%$ of victims of sexual exploitation of all victims of trafficking (United Nations Office on Drugs and Crime/UNODC, 2016). No country is not affected by trafficking in persons, including developed countries.

In combating trafficking, people use criminal sanctions, especially imprisonment sanctions which are types of crimes that are generally imposed by the court on traffickers but varying the number of crimes imposed by the court in deciding cases of trafficking to create a disparity in criminal proceedings (Ali \& Pramono, 2011). This will create a sense of dissatisfaction in the community and can lead to problems in prison administration and prisoners who have been convicted for a long time, from other prisoners but committing similar crimes will feel treated unfairly. Not only the maximum sanction. Maximum criminal sanctions are not only in the form of heavy penalties but can also provide additional types of 
criminal sanctions. Criminal individualization has the characteristics of personal principle, the principle of culpability, and the principle of flexibility, and the principle of modification (Arief, 2010a). Then the court is not given full freedom to adjust the crime that will be imposed with the personal circumstances of the perpetrator, this is following the opinion of Sheldon Glueck in Arief (2010b) that to determine the individualization of coaching to the offender does not mean having to leave the court at all, in this case, the judges or apparatus other apparatus without guidelines or control. Penalty guidelines can assist the court in considering penalties so that criminal convictions will be more proportional and better understood because of the conviction. Criminal guidelines as a direction in considering the weighting and relief of sentences against perpetrators of crimes of trafficking in persons where the crime of trafficking in persons is a serious crime. Therefore, the problem is the burdensome and mitigating factors that must be considered in imposing a crime against traffickers. The purpose of the discussion of this problem is to explain the differences of factors that are burdensome and mitigate in imposing penalties against traffickers. The background of this study is that penalization is not only oriented towards the perpetrators of crimes of trafficking in persons but also oriented to the interests of victims and the community so that criminal justice aims to integrally protect various interests. The study aims to identify the punishment of criminals of trafficking in persons based on the interests of victims in Indonesian court practices as outlined by some regulations and the international community as outlined by UNODC. Considering that the study is a transnational crime, the point of view used in this study is clear to analyze the perspective of the national community and the international community. Hence, the standard imeasuring instrument used the perspective of international justice and its practical implementation by the Indonesian court.

\section{LITERATURE REVIEW}

Penalization and criminal offenses receive less attention than attention to criminal acts or actions and mistakes with accountability. Whereas crime and punishment are the most important part of criminal law. Perpetrators with crimes have a strong relationship. According to Beccaria (2009), the basis for a criminal conviction is to let the punishment fit the crime, which means that criminal punishment must prevent crime from occurring. Criminal punishment or giving is inseparable from the influence of classical, modern, and neo-classical traditions in criminal law (Zulfa,
2011). The classical theory is oriented towards action, modern theory sees criminals because of actions and mistakes while neo-classical theory combines classical and modern, between perpetrators and deeds so as not to separate perpetrators and deeds. This theory still influences criminal law, a neo-classical school now developing that balances actions and mistakes.

The formulation of criminal and criminal penalties in the law is essentially only a means to achieve the goal of punishment. The development of thinking about criminal purposes occurs more towards a more rational direction. Therefore, thoughts that characterize a sense of justice in criminality bring up various goals of punishment. The principle of punishment used in countries in the world varies according to the legal system of each country. As for the Anti Human Trafficking Manual for Criminal Justice Practitioners Module 14, there is a dominant principle of punishment reflected in various legal systems, namely proportionality, retribution or denunciation, deterrence (both general and specific), rehabilitation, incapacitation or separation, and reparation (UNODC, 2009). The principle of punishment from UNODC above is based on the combined theory of punishment. A criminal is not a goal, but a criminal is a means or tool to achieve legal goals, although criminal and criminal objectives are interrelated. Criminal law is determined to be influenced by criminal objectives which contain principles of punishment.

\section{RESEARCH METHOD}

The method used is a library research method based on secondary data and legal materials. The legal material used by the convention and the literature relating to the scope of the discussion. The study also used the normative juridical method. A normative juridical approach is an approach that is based on the main legal material by examining theories, concepts, legal principles that apply in a certain country or international treaties.

\section{RESULTS}

The criminal sentence handed down by the court prioritizes the protection of the public against the crime of trafficking in persons without prejudice to the principle of criminal individualization which is oriented towards individual perpetrators. Penalties against traffickers in addition to paying attention to the rules of criminalization in trafficking laws relating to the type of criminal and criminal length, but also based on 
considerations that are in harmony with previous decisions that have ever existed, harmonious with a sense of community justice and harmonious with a sense of justice convicted person, so that feelings of dissatisfaction with the judge's ruling and marked disparity can be reduced. The court gives a rational, clear, directed, and proportional consideration. Penalties given to offenders will vary due to different jurisdictions, legal culture, jurisprudence, national legal practices, and different policy objectives. Awareness of these factors will help law enforcement in imposing penalties based on the severity of the violations committed and the consequences of crimes against victims, family, community, and country.

Human trafficking is a violation of human rights, often called modern slavery which has serious consequences both for victims and their families as well as society and the country. Destroyed the quality of life of victims and lost lives of victims, while the effects on society can slowly destroy social institutions. If this is carried out sustainably, then it poses a strategic risk to the stability of society and the country in the future. The whole situation is disrupting domestic economic investment, giving rise to political instability and national security that is destroying the entire order of life and welfare of the people which leads to the collapse of a nation. Trafficking in persons continues to be a major problem that can result in disrupting the stability of the population or the wider community to the world community.

Seeing the consequences of trafficking in persons and trafficking in persons including transnational and organized crime, trafficking in persons is a serious crime, stated in the United Nations Convention Against Transnational Organized Crime (UNTOC). For serious crimes the threat of a minimum sentence of four years or more severe, this is stated in Article 2 letter $b$ UNTOC namely "Serious crime" shall mean conduct constituting an offense punishable by a maximum deprivation of liberty of at least four years or a more serious penalty ". Countries that have ratified this convention must take the necessary actions or steps such as harmonizing legislation by the principle of sovereignty and territorial integrity of the country concerned. In general, criminal threats in crime there are several models (National Legal Development Agency, 2010). One type is threatened as a single criminal threat except for capital punishment, it must always be alternated with life imprisonment or imprisonment for a certain time. Crimes are threatened with a combination of alternative-cumulative.
The threat of criminal trafficking varies by country depending on the legal system in force in the country. Countries in the law governing trafficking in persons use alternative crimes as in the Dutch Penal Code, the Swiss Penal Code. Some countries that have the threat of trafficking in persons use cumulatively such as Indonesian Criminal Act of Trafficking, Indonesian Trafficking Crime Act, Chinese Penal Code, French Penal Code. Turkish Penal Code. A single criminal threat to traffickers as in the Russian Penal Code.

Determining the length of a crime or the amount of a fine in law varies from country to country. Some laws determine criminal sanctions with minimum-maximum imprisonment and minimum and maximum fines. Some use criminal sanctions with minimal and maximum imprisonment. Articles are using maximum imprisonment sanctions and maximum fines and there are also those using maximum imprisonment sanctions. The system of minimum and maximum sanctions, the court or judge impose a criminal between the lowest and highest criminal. Also, each human trafficking case has its characteristics caused by the condition of the perpetrator, the victim, or the situation at the time of the crime of trafficking in persons, which can be considered as a weighting or mitigation of crimes.

The court in imposing a crime based on the applicable law, besides that, considers the aggravating factors and mitigating factors. Incriminating factors are circumstances in the case that can increase the sentence specified and mitigating factors are circumstances in the case that can reduce penalties. The burdensome and lightening factors are special, where the different burdensome factors and lighten each case. There are states which state explicitly the burdensome factors in their laws, there are also countries that are fundamental to jurisprudence.

To determine the factors which incriminate or alleviate the crime of trafficking in persons, it is necessary to guide the penalties in the crime of trafficking in persons. In the international instrument, there is already a criminal guideline by setting minimum standards following the United Nations Convention Against Transnational Organized Crime (UNTOC) Article 11 (1), namely "each State Party shall make the commission of an offense established following articles $5,6,8$ and 23 of this Convention liable to sanctions that take into account the gravity of that offence". So the criminal imposed must be precise and proportional to the severity of the crime, therefore the implementation 
steps are adjusted to the requirements of this convention, where serious crimes are threatened with a maximum sentence of at least four years (Article 2 number b). In implementing this convention the International Framework for Action to Implement the Trafficking in Persons Protocol regulates, it states that the five operational indicators of implementing trafficking sanctions are (UNODC, 2009)severity of sanctions imposed for trafficking in persons; the number of sanctions reflecting aggravating circumstances; the number of additional administrative and/or other non-criminal sanctions used; Number of penal sanctions applied; and number of recidivist/repeat offenders.

UNODC mentions that 13 factors are burdensome to increase the seriousness of the crime of trafficking in persons (Cameron \& Schloenhardt, 2012). It includes that the offence involves serious injury or death of the victim or another person, including death as a result of suicide; and the offence involves a particularly vulnerable victim, including a pregnant woman. According to the Anti Human Trafficking Manual for Criminal Justice Practitioners Module 14, the aggravating factors are as (UNODC et al., 2009), previous convictions, particularly for trafficking offences; the offence was motivated by bias, prejudice, or hate based on race, religion, sex, age or other personal characteristics that are immutable; the offence involved planning and deliberation, etc. In connection with concerns about the phenomenon of trafficking in persons among the European Union countries, the European Parliament and the Council adopted the Legislative Act namely Directive 2011/36/EU of the European Parliament and the Council instructing that traffickers be punished with the following conditions (Buzek \& Gyori, 2011). Based on the discussion above, it can be concluded that weights are imposed for the perpetrators of trafficking in persons.

With the existence of these criminal charges, the court can consider the above weighting to determine the criminal severity. The weighting of the conviction is not limited because the weighting of the conviction is a minimum of a judge or court must consider if there are other things that according to the judge or court need to be added then the judge or court can add them. The relief of punishment to reduce penalties refers to all aspects of cases of trafficking in persons. The mitigating factors in trafficking are first-time offender, character, remorse or conduct following arrest, offender's age, etc (UNODC, 2009). Haynes (2019), states that the factor in leniency in trafficking in persons include no previous convictions or no relevant/recent convictions; remorse, age, and mental disorder.

The results of research from Jacobson and Hough (2007), that the commutation of punishment refers to the factors that have many forms of actors associated with the offender's past, the response to the offence, and prosecution and prospects. The light sentence for perpetrators of trafficking in persons refers to the internal factors of the perpetrators and the minor role in trafficking in persons which generally has less impact on the risk of serious harm. The role of perpetrators of trafficking in persons tends to be considered the same as committing trafficking in persons, considering that trafficking in persons is a very serious crime or extraordinary crime.

Thus the lightness of the sentence against the perpetrators of trafficking in persons is more oriented to factors relating to the perpetrators of the crime than trafficking in persons. Therefore the factor in criminal relief relates to the background or condition of the offender or the response of the offender when committing and after committing a crime of trafficking in persons.

Based on the discussion, it can be concluded that the commemoration of punishment for the perpetrators of trafficking in persons. Penalty relief for traffickers is the knowledge that is lacking (layman) and deceived; before committing trade crimes, the offender has good character; perpetrators also become victims of trafficking and demonstrate responsibility or regret by making improvements to the consequences of the crime of trafficking in persons. In addition to weighting considerations, the court can also consider the relief of punishment by taking into account the principle of proportionality. The carefulness of the judge or the court in considering mitigation is necessary so that the relief of this sentence does not reduce the spirit of combating the crime of trafficking in persons.

By using international perspectives, there is the influence of the legal systems adopted by various countries, that give the effect on the objectives of the punishment adopted by each legal system, and the disparity in their lapplication in each country. Each human trafficking crime case has different characteristics due to the condition of the perpetrator, the victim, the situation when the trafficking crime was committed. Therefore, as a practical consideration, the Indonesian court considers these factors which can be considered as a weighting or a reduction in sentence. 
The problem is incriminating and mitigating factors that must be considered in imposing penalties against traffickers. The study offers originality in investigating the factors which are burdensome and mitigate in imposing crimes against traffickers.

\section{CONCLUSION}

The findings underline the principle of criminalization as the basis for imposing penalties on perpetrators of trafficking in persons by taking into account the factors of weighting and mitigation of punishment, in which the proportional principle takes precedence in addition to the other principles. This study is about the factors that influence the severity of the crime against traffickers but focuses on the criminal process in court.

As particular in the Indonesian criminal code, criminalization of trafficking in persons is based on the principles of criminalization that reflect the objectives of integrative criminalization which are concerned with the interests of the perpetrators, victims, and the community in order to achieve the goal of criminal justice that is fair to all parties. The judgment of weighting and legal relief in deciding cases of trafficking in persons is carried out by judges or courts based on proportional principles and other principles that are included in the principles of criminalization, therefore criminal guidelines are needed as a direction to consider the prosecution and relief of trafficking crimes.

The theoretical contribution of this study is that each human trafficking crime case has different characteristics due to the condition of the perpetrator, the victim, the situation when the trafficking crime was committed. Therefore, as a practical contribution, the Indonesian court considers these factors which can be considered as a weighting or a reduction in sentence. The problem is incriminating and mitigating factors that must be considered in imposing penalties against traffickers.

Further studies should consider the cross-border law enforcement process, based on the UN Model
Treaty on Mutual Assistance in Criminal Matters, which has experienced various constraints of differences in legal systems and extradition lagreements, as well as the integration of the criminal law system and the civil law system in asset sharing

\section{REFERENCES}

Ali, M., \& Pramono, B. A. (2011). Trafficking in persons: dimensions, international instruments and arrangements in Indonesia. Citra Aditya Bakti.

Arief, B. N. (2010a). Legislative Policy in Handling Prison Crimes. Semarang: Diponegoro University.

Arief, B. N. (2010b). Development of the principles of Indonesian criminal law: a comparative perspective of criminal law. Diponegoro University.

Atmasasmita, R. (2016). Business Crime Law: Theory \& Practice in the Era of Globalization. Prenada Media.

Beccaria, C. (2009). On crimes and punishments and other writings. University of Toronto Press.

Buzek, J., \& Gyori, E. (2011). Directive 2011/36 / EU of the European Parliament and of the Council of 5 April 2011 on Preventing and Combating Trafficking in Human Beings and Protecting Its Victims, and Replacing Council Framework Decision 2002/629 / JHA. Official Journal of the European Union, 10 (101), 1-01.

Cameron, M., \& Schloenhardt, A. (2012). Punishing trafficking in persons: International standards and Australian experiences. Bond L. Rev., 24, i.

Haynes, J. (2019). Caribbean Anti-Trafficking Law and Practice. Bloomsbury Publishing. https://doi.org/10.5040/9781509915590

Jacobson, J., \& Hough, M. (2007). Mitigation: The role of personal factors in sentencing. Project Report. Prison Reform Trust, London, UK

National Legal Development Agency. (2010). National Law Development Planning in the field of criminal law and the criminal system (legal politics and punishment). National Legal Development Agency

Nuraeny, H. (2015). Pengiriman Tenaga Kerja Migran Sebagai Salah Satu Bentuk Perbudakan Modern dari Tindak Pidana Perdagangan Orang. Jurnal Hukum dan Peradilan, 4(3), 501518. https://doi.org/10.25216/JHP.4.3.2015.501-518

United Nations Office on Drugs and Crime (UNODC). (2009). AntiHuman Trafficking Manual for Criminal Justice Practitioners. Austria: UNODC Vienna International Ctr.

United Nations Office on Drugs and Crime (UNODC). (2016). International Framework for Action to Implement the Trafficking in Persons Protocol. United Nations Office on Drugs and Crime

Zulfa, E. A. (2011). Shifting the criminal paradigm. Lubuk Agung.

https://doi.org/10.6000/1929-4409.2021.10.79

(C) 2021 Farhana Farhana; Licensee Lifescience Global.

This is an open access article licensed under the terms of the Creative Commons Attribution Non-Commercial License (http://creativecommons.org/licenses/by-nc/3.0/) which permits unrestricted, non-commercial use, distribution and reproduction in any medium, provided the work is properly cited. 